\title{
Synthesis and X-ray crystal structure of diimidosulfinate tran- sition metal complexes
}

\author{
Melike Bayram, Dieter Bläser, Christoph Wölper, Stephan Schulz* \\ Institute of Inorganic Chemistry, University of Duisburg-Essen, Universitätsstr. 5-7, D-45117 Essen, \\ Germany.
}

Supporting Information Placeholder

\begin{abstract}
Bis(trimethylsilyl) sulfurdiimide $\mathrm{S}\left(\mathrm{NSiMe}_{3}\right)_{2}$ reacts with equimolar amounts of $\mathrm{Me}_{2} \mathrm{Zn}$ and $\mathrm{Cp}_{2}{ }_{2} \mathrm{Zn}$ either with insertion into the metal-carbon bond and formation of the expected S-methyl diimidosulfinate

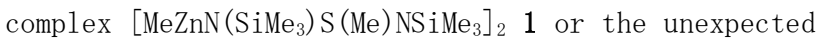
complex $\left\{\mathrm{Me}_{3} \mathrm{SiNS}\left[\mathrm{N}\left(\mathrm{SiMe}_{3}\right) \mathrm{SNSiMe}_{3}\right] \mathrm{N}\left(\mathrm{SiMe}_{3}\right) \mathrm{Zn}\right\}_{2}$ 2. Insertion reactions were also observed with $\mathrm{Cp}^{*} \mathrm{MMe}_{3}(\mathrm{M}=$ $\mathrm{Ti}, \mathrm{Zr}$, Hf), yielding $\mathrm{Cp}^{*}(\mathrm{Me})_{2} \mathrm{M}\left[\mathrm{Me}_{3} \mathrm{SiNS}(\mathrm{Me}) \mathrm{NSiMe}_{3}\right] \quad(\mathrm{M}$ $=\mathrm{Ti} 3, \mathrm{Zr} 4$, Hf 5), whereas the corresponding $\mathrm{Cl}^{-}$ substituted derivatives $\mathrm{Cp}^{*}(\mathrm{Cl})_{2} \mathrm{M}\left[\left(\mathrm{Me}_{3} \mathrm{SiNS}(\mathrm{Me}) \mathrm{NSiMe}_{3}\right]\right.$ (M = Ti 6, Zr 7, Hf 8) were obtained from salt elimination reactions of Li S-methyl diimidosulfinate $\left(\mathrm{Me}_{3} \mathrm{SiN}\right)_{2} \mathrm{~S}(\mathrm{Me}) \mathrm{Li}($ thf $\left.)\right]_{2} 9$ with $\mathrm{Cp}^{*} \mathrm{MCl}_{3} . \quad 1-8$ were characterized by heteronuclear NMR $\left({ }^{1} \mathrm{H},{ }^{13} \mathrm{C}\right)$ and $\mathrm{IR}$ spectroscopy and the solid state structures of $1-5$ and 9 were determined by single crystal X-ray diffraction.
\end{abstract}

\section{Introduction}

Monoanionic S-alkyl diimidosulfinates [RS(NR' $)_{2}$ ] belong to the well known group of monoanionic heteroallyl ligands, which have been found widespread applications in coordination chemistry (Scheme 1). ${ }^{[1]}$

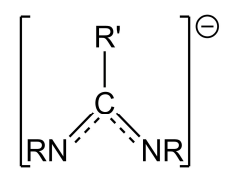

Amidinates

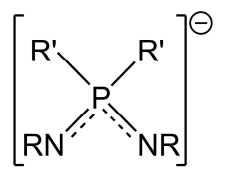

Diiminophosphinates<smiles>[R]S([18O])(=[18O])=[W]</smiles>

Diiminosulfinates
Scheme 1. Monoanionic heteroallyl ligands.

These ligands show different binding modes to metals and can serve as monodentate $\left(\eta^{I}\right)$, chelating $\left(\eta^{2}\right)$ or bridging monodentate $\left(\mu-\eta^{I}-\eta^{I}\right)$ fourelectron donor ligands. They have also been referred as "steric cyclopentadienyl equivalents" since their cone angles are comparable to those of $\mathrm{C}_{5} \mathrm{H}_{5}{ }^{-}$and $\mathrm{C}_{5} \mathrm{Me}_{5}$ respectively, ${ }^{[2]}$ and as a consequence, they have been found technical applications in catalysis such as olefin polymerization. ${ }^{[3]}$
S-alkyl diimidosulfinates are typically prepared by reaction of the corresponding sulfurdiimide $\mathrm{S}(\mathrm{NR})_{2}$ with different organometallic compounds RM. ${ }^{[4]}$ Alkali metal organyls are of particular interest since the resulting complexes are valuable diimidosulfinatetransfer reagents due to their high solubility in organic solvents. Lithium diimidosulfinates are easily accessible by reaction of sulfurdiimides with lithium organyls, in which the nucleophilic carbanion attacks the electrophilic sulfur atom. As a consequence, a large number of lithium diimidosulfinate compounds containing different S-organo substituents have been synthesized and their structure have been investigated by X-ray diffraction and solid state NMR spectroscopy. ${ }^{[5]}$ They typically form solvent stabilized monomers or dimeric molecules in the solid state, whereas the corresponding Grignard reagents are predominantly monomeric. ${ }^{[1 b]}$ Moreover, Stalke et al. successfully applied this particular synthetic approach also for the synthesis of Janus-type multidentate ligands as well as spacer-bridged bis(diimidosulfinates). ${ }^{[6,7]}$ In addition to the well known alkali metal and alkaline earth metal diimidosulfinates $\left[\mathrm{RS}\left(\mathrm{NR}^{\prime}\right)_{2}\right][\mathrm{M}(\mathrm{solv})][\mathrm{M}=\mathrm{Li}, \mathrm{Na}, \mathrm{K}$, $\mathrm{Rb}, \mathrm{Cs} ; \mathrm{MgX}]$, which are accessible either by treating sulfurdiimides with different Grignard reagents or by reaction of $\quad N, N^{\prime}$-bis(trimethylsilyl)aminoiminphenylsulphine $\mathrm{PhS}\left(\mathrm{NSiMe}_{3}\right) \mathrm{N}(\mathrm{H}) \mathrm{SiMe}_{3}$ with bis (trimethylsilyl) amides $\left[\mathrm{M}\left\{\left(\mathrm{N}\left(\mathrm{SiMe}_{3}\right)_{2}\right\}\right](\mathrm{M}=\mathrm{Ca}, \mathrm{Sr}\right.$, $\mathrm{Ba}),{ }^{[8,9]}$ several experimental studies on the synthesis of other main group and transition metal diimidosulfinates complexes have been reported. They are almost exclusively synthesized by reaction of the alkali metal diimidosulfinates with the corresponding metal halides or amides. ${ }^{[7,10]}$ Moreover, simple Lewis acidbase adducts of sulfurdiimide with several metal halides such as $\mathrm{TiCl}_{4}, \mathrm{GaCl}_{3}$ and $\mathrm{SnCl}_{4}$, respectively, have been synthesized, ${ }^{[11]}$ while Weidlein et al. reported on insertion reactions of bis (trimethylsilyl) sulfurdiimide with trimethylalane, -gallane and -indane $\mathrm{MMe}_{3}(\mathrm{M}=\mathrm{Al}, \mathrm{Ga}, \mathrm{In}) .{ }^{[11 \mathrm{c}]} \mathrm{In}$

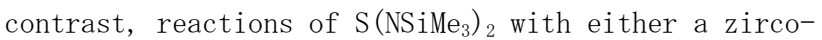
nium imide or the titanocene alkyne complex $\left[\mathrm{Cp}_{2} \mathrm{Ti}\left(\eta^{2}-\right.\right.$ 
$\left.\mathrm{Me}_{3} \mathrm{SiC}_{2} \mathrm{SiMe}_{3}\right)$ ] yielded titanium trisimidosulfite complexes in a rather complex reaction mechanism, ${ }^{[12,13]}$ while the analogous reaction with $\left[\mathrm{Cp}_{2} \mathrm{Ti}\left(\eta^{2}-\right.\right.$ $\left.\mathrm{Me}_{3} \mathrm{SiC}_{2} \mathrm{SiMe}_{3}\right)$ ] gave an unusual four-membered metallacycle. ${ }^{[14]}$

Surprisingly, reactions of sulfurdiimides with homoleptic group 12 ( $\mathrm{Zn}$ ) metal complexes $\mathrm{MR}_{2}$ as well as heteroleptic group 4 complexes $\mathrm{Cp}^{*} \mathrm{MMe}_{3}(\mathrm{M}=\mathrm{Ti}, \mathrm{Zr}$, Hf), in which the organic groups also exhibits a high carbanionic character, have not been reported to the best of our knowledge. In contrast, sulfurtriimides $\mathrm{S}(\mathrm{NR})_{3}$ were shown to react with $\mathrm{ZnMe}_{2}$ with insertion into the metal-carbon bond and formation of the zincS-methyltri (tert-butylimido) sulfonate $\mathrm{Me}_{\mathrm{x}} \mathrm{M}\left[(\mathrm{RN})_{3} \mathrm{SMe}\right]$ $(M=Z n, \quad x=1 ; M=A 1, \quad x=2) .{ }^{[15]}$ Due to our general interest in the synthesis, structure and catalytic activity of transition metal complexes containing chelating N, N'-, N, $0^{-}$and $0,0-$ ligands, ${ }^{[16]}$ we became interested in reactions of bis(trimethylsilyl)sulfurdiimide with group 4 and group 12 metal complexes containing metal-Me bonds and report herein on reactions of $\mathrm{S}\left(\mathrm{NSiMe}_{3}\right)_{2}$ with $\mathrm{Me}_{2} \mathrm{Zn}, \mathrm{Cp}_{2}{ }_{2} \mathrm{Zn}$ and group 4 metal complexes of the general type $\mathrm{Cp}^{*} \mathrm{MMe}_{3}$ (M $=\mathrm{Ti}$, $\mathrm{Zr}$, Hf). In addition, salt elimination reactions between $\mathrm{Cp}^{*} \mathrm{MCl}_{3} \quad(\mathrm{M}=\mathrm{Ti}, \mathrm{Zr}, \mathrm{Hf})$ and S-methy1diimidosulfinate $\left\{\mathrm{Li}(\mathrm{thf})\left[\mathrm{Me}_{3} \mathrm{SiNS}(\mathrm{Me}) \mathrm{NSiMe}_{3}\right]\right\}_{2}$, which

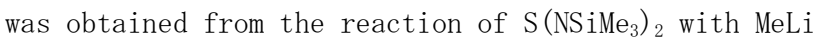
in thf, yielded the corresponding S-alkyl diimidosulfinates.

\section{Experimental Section}

General Procedures. Al1 manipulations were performed in a Glovebox (MBraun) under an Ar atmosphere or with standard Schlenk techniques. Solvents were carefully dried over $\mathrm{Na} / \mathrm{K}$ and degassed prior to use. A $2 \mathrm{M}$ solution of $\mathrm{ZnMe}_{2}$ in toluene was obtained from Sigma Aldrich and used as received, while $\mathrm{S}\left(\mathrm{N}\left(\mathrm{SiMe}_{3}\right)_{2},{ }^{[17]} \mathrm{ZnCp}_{2}{ }_{2},{ }^{[18]} \mathrm{Cp}^{*} \mathrm{MMe}_{3},{ }^{[19]}\right.$ and $\mathrm{Cp}^{*} \mathrm{MCl}_{3},{ }^{[20]}$ were prepared according to literature methods. Due to the high vapor pressure of $\mathrm{ZnMe}_{2}$ and its high reactivity toward water and oxygen, all manipulations must be performed under inert gas conditions. NMR spectra were recorded on a Bruker Avance 300 spec- $^{-}$ trometer at $25{ }^{\circ} \mathrm{C}$ at $300.1 \mathrm{MHz} \quad\left({ }^{1} \mathrm{H}\right)$ and $75.5 \mathrm{MHz}$ $\left({ }^{13} \mathrm{C}\right)$, respectively, and referenced to internal $\mathrm{C}_{6} \mathrm{D}_{5} \mathrm{H}$ $\left({ }^{1} \mathrm{H}: \delta=7.154 ;{ }^{13} \mathrm{C}: \delta=128.0\right)$ and internal $\mathrm{THF}-\mathrm{d}_{8}$ $\left({ }^{1} \mathrm{H}: \delta=3.580,1.730 ;{ }^{13} \mathrm{C}: \delta=25.2,67.4\right)$. IR spectra were recorded on a Bruker ALPHA-T FT-IR spectrometer equipped with a single reflection ATR sampling module. Melting points were measured in sealed capilaries and were not corrected. Elemental analyses were performed at the Elementaranalyse Labor of the University of Duisburg-Essen.

$\left[\mathrm{MeZnN}\left(\mathrm{SiMe}_{3}\right) \mathrm{S}(\mathrm{Me}) \mathrm{NSiMe}_{3}\right]_{2} \quad$ 1. $\mathrm{S}\left(\mathrm{NSiMe}_{3}\right)_{2} \quad(0.50 \mathrm{~g}$, $2.42 \mathrm{mmol}$ ) was dissolved in $3 \mathrm{ml}$ of toluene and 2.02 $\mathrm{ml} \mathrm{ZnMe}_{2}$ (2. $42 \mathrm{mmol} ; 1.2 \mathrm{M}$ in toluene) was added to the yellow solution at ambient temperature. After 15 min of stirring a colorless solution was obtained.
The solvent was reduced and colorless crystals were obtained after storage at $-30{ }^{\circ} \mathrm{C}$ for 12 hours.

Yield: $1.43 \mathrm{~g}(98 \%)$. Mp. $49{ }^{\circ} \mathrm{C}$. Anal. Found (calcd) for $\mathrm{C}_{16} \mathrm{H}_{48} \mathrm{~N}_{4} \mathrm{~S}_{2} \mathrm{Si}_{4} \mathrm{Zn}_{2} \quad(603.80 \mathrm{~g} / \mathrm{mol}): \quad$ C, 32.15 (31.83); $\mathrm{H}, \quad 8.08(8.01) ; \mathrm{N}, 9.53(9.27) ; \mathrm{S}, 10.50(10.62) \%$. ${ }^{1} \mathrm{H}$ NMR $\left(300 \mathrm{MHz}, \quad \mathrm{C}_{6} \mathrm{D}_{6}, 25{ }^{\circ} \mathrm{C}\right): \delta=-0.30(\mathrm{~s}, 6 \mathrm{H}$, $\mathrm{ZnMe}), 0.23(\mathrm{~s}, 36 \mathrm{H}, \mathrm{SiMe}), 2.83(\mathrm{~s}, 6 \mathrm{H}, \mathrm{SMe}) .{ }^{13} \mathrm{C}$ NMR $\left(75 \mathrm{MHz}, \quad \mathrm{C}_{6} \mathrm{D}_{6}, \quad 25{ }^{\circ} \mathrm{C}\right): \delta=-5.27 \quad(\mathrm{ZnMe}), \quad 1.99$ $\left(\mathrm{Si} M e_{3}\right), 48.09$ (SMe). ATR-IR: $v=2949,2901,2830$, 1414, 1294, 1245, 1161, 1051, 978, 967, 909, 826, 773, 748, 706, 677, 623, 516, 439, $382 \mathrm{~cm}^{-1}$.

$\left\{\mathrm{Me}_{3} \mathrm{SiNS}\left[\mathrm{N}\left(\mathrm{SiMe}_{3}\right) \mathrm{SNSiMe}_{3}\right] \mathrm{N}\left(\mathrm{SiMe}_{3}\right) \mathrm{Zn}\right\}_{2}$ 2. $\mathrm{ZnCp}_{2}{ }_{2} \quad(0.30$ g, $0.97 \mathrm{mmol}$ ) was dissolved in $5 \mathrm{ml}$ of toluene and $\mathrm{S}\left(\mathrm{NSiMe}_{3}\right)_{2}(0.30 \mathrm{~g}, 1.45 \mathrm{mmol})$ was added to the solution at ambient temperature. The yellow solution turned orange within 2 hours. The solvent was reduced and colorless crystals were obtained after storage at $-30{ }^{\circ} \mathrm{C}$ for 12 hours.

Yield: $0.27 \mathrm{~g}(30 \%)$. Mp. $146{ }^{\circ} \mathrm{C}$ (dec.). Anal. Found (calcd) for $\mathrm{C}_{24} \mathrm{H}_{72} \mathrm{~N}_{8} \mathrm{~S}_{4} \mathrm{Si}_{8} \mathrm{Zn}_{2} \quad$ (956.59 g/mol): C, 30.25 (30.13); H, 7.46 (7.59); N, 11.35 (11.71); S, 13.0 (13.41) \%. ${ }^{1} \mathrm{H}$ NMR $\left(300 \mathrm{MHz}, \mathrm{C}_{6} \mathrm{D}_{6}, 25{ }^{\circ} \mathrm{C}\right): \delta=0.21(\mathrm{~s}$, $\left.9 \mathrm{H}, \mathrm{Si} \mathrm{Me}_{3}\right), 0.42\left(\mathrm{~s}, 9 \mathrm{H}, \mathrm{Si} \mathrm{Me}_{3}\right), 0.44$ (s, $9 \mathrm{H}$, $\left.\mathrm{Si}_{3 e_{3}}\right), 0.57\left(\mathrm{~s}, 9 \mathrm{H}, \mathrm{Si}_{3}\right) .{ }^{13} \mathrm{C} \mathrm{NMR}\left(75 \mathrm{MHz}, \mathrm{C}_{6} \mathrm{D}_{6}, 25\right.$ $\left.{ }^{\circ} \mathrm{C}\right): \quad \delta=0.89 \quad\left(\mathrm{Si}_{M}\right), 2.10 \quad\left(\mathrm{Si} M e_{3}\right), 2.34 \quad\left(\mathrm{Si}_{3}\right)$, 3. 01 (Si $\left.\mathrm{Me}_{3}\right)$. ATR-IR: $v=2949,2896,1442,1402$, $1244,987,900,875,825,769,713,676,663,617$, 486, 427, $409 \mathrm{~cm}^{-1}$.

General synthesis of $3-5$. $0.48 \mathrm{mmol} \mathrm{Cp}^{*} \mathrm{MMe}_{3} \quad(\mathrm{M}=$ Ti 3, $0.09 \mathrm{~g}$; Zr 4, $0.11 \mathrm{~g}$; Hf 5, $0.15 \mathrm{~g})$ was dissolved in $5 \mathrm{ml}$ fluorobenzene and $\mathrm{S}\left(\mathrm{NSiMe}_{3}\right)_{2}(0.10 \mathrm{~g}$, $0.48 \mathrm{mmol}$ ) was added via syringe. The solution was stirred at $50{ }^{\circ} \mathrm{C}$ for 15 hours and the solvent was removed in vacuum. Crystals were obtained from a solution in $1 \mathrm{~mL}$ of pentane at $18{ }^{\circ} \mathrm{C}$.

$\mathrm{Cp}^{*}(\mathrm{Me})_{2} \mathrm{Ti}\left[\mathrm{Me}_{3} \mathrm{SiNS}(\mathrm{Me}) \mathrm{NSiMe}_{3}\right]$ 3. Yield: $0.18 \mathrm{~g} \quad(85$ $\%$ ). Mp. $93{ }^{\circ} \mathrm{C}$ (dec.). Anal. Found (calcd) for $\mathrm{C}_{19} \mathrm{H}_{42} \mathrm{~N}_{2} \mathrm{SSi}_{2} \mathrm{Ti} \quad(434.68 \mathrm{~g} / \mathrm{mol}): \quad \mathrm{C}, \quad 52.25 \quad(52.50) ; \mathrm{H}$, $9.71(9.74) ; \mathrm{N}, 6.37(6.44) \mathrm{S}, 7.18(7.38) \% .{ }^{1} \mathrm{H}$ NMR $\left.\left(300 \mathrm{MHz}, \quad \mathrm{C}_{6} \mathrm{D}_{6}, \quad 25{ }^{\circ} \mathrm{C}\right): \delta=0.24\left(\mathrm{~s}, \quad 18 \mathrm{H}, \quad \mathrm{Si}_{M}\right)_{3}\right)$, $0.63\left(\mathrm{~s}, 6 \mathrm{H}, \mathrm{Ti} M e_{2}\right), 1.94\left(\mathrm{~s}, 15 \mathrm{H}, \mathrm{C}_{5} M e_{5}\right), 2.05(\mathrm{~s}$, $3 \mathrm{H}, \quad \mathrm{S} M e) .{ }^{13} \mathrm{C}$ NMR $\left(75 \mathrm{MHz}, \mathrm{C}_{6} \mathrm{D}_{6}, \quad 25{ }^{\circ} \mathrm{C}\right): \delta=2.68$ $\left(\mathrm{Si} M e_{3}\right), \quad 13.30 \quad(\mathrm{TiMe}), \quad 48.80 \quad(\mathrm{SMe}), \quad 65.25 \quad\left(\mathrm{C}_{5} \mathrm{Me}_{5}\right)$, 123. $26\left(C_{5} \mathrm{Me}_{5}\right)$. ATR-IR: $v=2957,2910,1727$, 1489, $1407,1377,1284,1261,1245,1135,1101,1024,980$, 921, 833, 802, 705, 677, 627, 595, 439, $406 \mathrm{~cm}^{-1}$.

$\mathrm{Cp}^{*}(\mathrm{Me}){ }_{2} \mathrm{Zr}\left[\mathrm{Me}_{3} \mathrm{SiNS}(\mathrm{Me}) \mathrm{NSiMe}_{3}\right]$ 4. Yield: $0.21 \mathrm{~g} \quad(90$ \%). Mp. $83{ }^{\circ} \mathrm{C}$ (dec.). Anal. Found (calcd) for $\mathrm{C}_{17} \mathrm{H}_{36} \mathrm{~N}_{2} \mathrm{SSi}_{2} \mathrm{Zr} \quad(478.00 \mathrm{~g} / \mathrm{mol}): \quad \mathrm{C}, \quad 47.75 \quad(47.74) ; \quad \mathrm{H}$, $8.86(8.86)$; N, $5.89(5.86)$; S, 6.73 (6.71)\%. ${ }^{1} \mathrm{H}$ NMR $\left(300 \mathrm{MHz}, \quad \mathrm{C}_{6} \mathrm{D}_{6}, 25{ }^{\circ} \mathrm{C}\right): \delta=0.19\left(\mathrm{~s}, 18 \mathrm{H}, \quad \mathrm{Si} M e_{3}\right)$, $0.28\left(\mathrm{~s}, 6 \mathrm{H}, \mathrm{ZrMe}_{2}\right), 2.02\left(\mathrm{~s}, 15 \mathrm{H}, \mathrm{C}_{5} \mathrm{Me}_{5}\right), 2.09$ ( $3 \mathrm{H}, \quad \mathrm{SMe}) .{ }^{13} \mathrm{C}$ NMR $\left(75 \mathrm{MHz}, \mathrm{C}_{6} \mathrm{D}_{6}, \quad 25{ }^{\circ} \mathrm{C}\right): \delta=2.40$

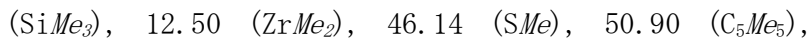
119. $85\left(C_{5} \mathrm{Me}_{5}\right)$. ATR-IR: $v=2955,2933,2920,2867$, $2805,2772,2726,1492,1439,1376,1279,1257,1244$, $1139,1116,992,830,793,752,695,676,658, \quad 555$, 506, 480, 459, $423 \mathrm{~cm}^{-1}$. 
$\mathrm{Cp}^{*}(\mathrm{Me}){ }_{2} \mathrm{Hf}\left[\mathrm{Me}_{3} \mathrm{SiNS}(\mathrm{Me}) \mathrm{NSiMe}_{3}\right] \quad$ 5. Yield: 0.28 g $\quad(88$ \%). Mp. $71{ }^{\circ} \mathrm{C}$ (dec.). Anal. Found (calcd) for $\mathrm{C}_{19} \mathrm{H}_{42} \mathrm{~N}_{2} \mathrm{SSi}_{2} \mathrm{Hf} \quad(565.39 \mathrm{~g} / \mathrm{mol}):$ C, 39.9 (40.37); H, 7.31 (7. 49); N, 4.91 (4.96); S, 5.42 (5.67)\%. ${ }^{1} \mathrm{H}$ NMR (300 $\left.\mathrm{MHz}, \mathrm{C}_{6} \mathrm{D}_{6}, 25{ }^{\circ} \mathrm{C}\right): \delta=0.05\left(\mathrm{~s}, 6 \mathrm{H}, \mathrm{Hf}_{\mathrm{Me}}\right), 0.18(\mathrm{~s}$, $18 \mathrm{H}, \quad \mathrm{SiMe}), 2.06\left(\mathrm{~s}, 18 \mathrm{H}, \quad \mathrm{C}_{5} \mathrm{Me}_{5}, \mathrm{SMe}\right) .{ }^{13} \mathrm{C} \mathrm{NMR}(75$ $\left.\mathrm{MHz}, \quad \mathrm{C}_{6} \mathrm{D}_{6}, \quad 25{ }^{\circ} \mathrm{C}\right): \quad \delta=2.40 \quad\left(\mathrm{Si}_{\mathrm{Me}_{3}}\right), \quad 12.39\left(\mathrm{Hf}_{\mathrm{Me}}\right)$, $53.28(\mathrm{SMe}), 67.83\left(\mathrm{C}_{5} \mathrm{Me}_{5}\right), 118.83\left(\mathrm{C}_{5} \mathrm{Me}_{5}\right)$. ATR-IR: $v=$ 2956, 2819, 2870, 2806, 2782, 1492, 1440, 1417, 1376, $1280,1245,1136,1128,1092,1065,1024,995,983$, $830,797,752,699,676,627, \quad 594, \quad 564, \quad 543, \quad 493$, $460,425 \mathrm{~cm}^{-1}$.

$\left[\left(\mathrm{Me}_{3} \mathrm{SiN}\right)_{2} \mathrm{~S}(\mathrm{Me}) \mathrm{Li}(\mathrm{thf})\right]_{2}$ 9. A solution of $\mathrm{S}\left(\mathrm{NSiMe}_{3}\right)_{2}$ (0.15 g, $0.73 \mathrm{mmol}$ ) in $5 \mathrm{~mL}$ of THF was cooled to -78 ${ }^{\circ} \mathrm{C}$ and $0.45 \mathrm{ml} \mathrm{MeLi} \mathrm{(0.73} \mathrm{mmol;} 1.6 \mathrm{M}$ in $\left.\mathrm{Et}_{2} 0\right)$ was added via syringe. The solution was allowed to reach ambient temperature and stirred for 1 h. 9 was isolated in quantitative yield after removal of the solvent. Re-crystallization from THF at $-30 \quad{ }^{\circ} \mathrm{C}$ gave colorless crystals of 9.

Yield: 0.43 g (98 \%). Anal. Found (calcd) for $\mathrm{C}_{22} \mathrm{H}_{58} \mathrm{~N}_{4} \mathrm{O}_{2} \mathrm{~S}_{2} \mathrm{Si}_{4} \mathrm{Li}_{2} \quad(601.08 \mathrm{~g} / \mathrm{mol}): \mathrm{C}, 43.87$ (43.96); H, $9.64(9.73) ; \mathrm{N}, 9.20(9.32) ; \mathrm{S}, \quad 10.56(10.67) \% .{ }^{1} \mathrm{H}$ NMR $\left(300 \mathrm{MHz}, \mathrm{C}_{6} \mathrm{D}_{6}, 25{ }^{\circ} \mathrm{C}\right): \delta=0.34\left(\mathrm{~s}, 18 \mathrm{H}, \quad \mathrm{SiMe}_{3}\right)$, 1.28 (m, $4 \mathrm{H}$, thf), 2.24 (s, $6 \mathrm{H}, \mathrm{SMe}), 3.48$ (m, $4 \mathrm{H}$, thf). ${ }^{13} \mathrm{C}$ NMR $\left(75 \mathrm{MHz}, \mathrm{C}_{6} \mathrm{D}_{6}, 25{ }^{\circ} \mathrm{C}\right): \delta=2.64\left(\mathrm{Si} M e_{3}\right)$, 25. 41 (thf), 53.49 (SMe), 68.30 (thf).

General synthesis of $6-8.0 .45 \mathrm{ml}$ MeLi (0.73 mmol; $1.6 \mathrm{M}$ in $\left.\mathrm{Et}_{2} \mathrm{O}\right)$ was added at $-78{ }^{\circ} \mathrm{C}$ to a solu-

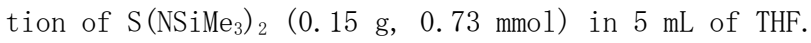
The resulting solution was warmed to ambient temperature, stirred for $1 \mathrm{~h}$ and then cooled to $-78{ }^{\circ} \mathrm{C}$. A

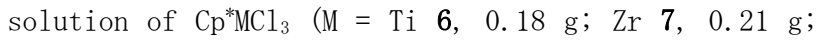
Hf $8,0.27 \mathrm{~g} ; 0.73 \mathrm{mmol}$ ) in $5 \mathrm{ml}$ of THF was slowly added and the resulting solution was warmed to ambient temperature. After stirring for 10 hours, the solvent was removed in vacuum and the residue was suspended in pentane, filtered and the solvent reduced in vacuum to $3 \mathrm{~mL}$. Crystals of $6-8$ were obtained after 12 hours at $18{ }^{\circ} \mathrm{C}$.

$\mathrm{Cp}^{*}(\mathrm{Cl})_{2} \mathrm{Ti}\left[\mathrm{Me}_{3} \mathrm{SiNS}(\mathrm{Me}) \mathrm{NSiMe}_{3}\right]$ 6. Yield: $0.10 \mathrm{~g} \quad(30$ \%). Mp. $142{ }^{\circ} \mathrm{C}$ (dec.). Anal. Found (calcd) for $\mathrm{C}_{17} \mathrm{H}_{36} \mathrm{Cl}_{2} \mathrm{~N}_{2} \mathrm{SSi}_{2} \mathrm{Ti} \quad(475.49 \mathrm{~g} / \mathrm{mol}): \mathrm{C}, 42.47$ (42.94); H, $7.54(7.63) ; \mathrm{N}, \quad 5.50(5.89) ; \mathrm{S}, 6.42(6.74) \% .{ }^{1} \mathrm{H}$ NMR $\left(300 \mathrm{MHz}, \mathrm{THF}-d_{8}, 25{ }^{\circ} \mathrm{C}\right): \delta=0.25(\mathrm{~s}, 18 \mathrm{H}, \mathrm{SiMe})$, $2.08\left(\mathrm{~s}, 15 \mathrm{H}, \mathrm{C}_{5} \mathrm{Me}_{5}\right), 2.78(\mathrm{~s}, 3 \mathrm{H}, \mathrm{SMe}) .{ }^{13} \mathrm{C} \mathrm{NMR}(75$ $\left.\mathrm{MHz}, \quad \mathrm{THF}-d_{8}, 25{ }^{\circ} \mathrm{C}\right): \delta=1.19\left(\mathrm{SiMe}_{3}\right), 12.68(\mathrm{SMe})$, 44. $64\left(\mathrm{C}_{5} \mathrm{Me}_{5}\right), 125.38\left(\mathrm{C}_{5} \mathrm{Me}_{5}\right)$. ATR-IR: $v=2954,2911$, 2857, 1433, 1407, 1308, 1289, 1250, 1015, 997, 956, $887,837, \quad 771, \quad 752, \quad 727,659,622,611, \quad 563, \quad 547$, $475,435,416,382 \mathrm{~cm}^{-1}$.

$\mathrm{Cp}^{*}(\mathrm{Cl})_{2} \mathrm{Zr}\left[\mathrm{Me}_{3} \mathrm{SiNS}(\mathrm{Me}) \mathrm{NSiMe}_{3}\right]$ 7. Yield: 0.11 g $(28$ \%). Mp. $205{ }^{\circ} \mathrm{C}$ (dec.). Anal. Found (calcd) for $\mathrm{C}_{17} \mathrm{H}_{36} \mathrm{Cl}_{2} \mathrm{~N}_{2} \mathrm{SSi}_{2} \mathrm{Zr} \quad(516.06 \mathrm{~g} / \mathrm{mol}): \mathrm{C}, 39.9 \quad(40.34) ; \mathrm{H}$, $7.13(7.17)$; N, 5.12 (5.53); S, 5.86 (6.34)\%. ${ }^{1} \mathrm{H}$ NMR $\left(300 \mathrm{MHz}, \mathrm{THF}-d_{8}, 25{ }^{\circ} \mathrm{C}\right): \delta=0.24(\mathrm{~s}, 18 \mathrm{H}, \mathrm{SiMe})_{3}$, $2.17\left(\mathrm{~s}, 15 \mathrm{H}, \mathrm{C}_{5} \mathrm{Me}_{5}\right), 2.70(\mathrm{~s}, 3 \mathrm{H}, \mathrm{S} M e) .{ }^{13} \mathrm{C} \mathrm{NMR}(75$ $\left.\mathrm{MHz}, \quad \mathrm{THF}-d_{8}, 25{ }^{\circ} \mathrm{C}\right): \delta=1.94\left(\mathrm{Si}_{\mathrm{Me}}\right), 13.39(\mathrm{SMe})$,
48. $31\left(\mathrm{C}_{5} \mathrm{Me}_{5}\right), 125.91\left(\mathrm{C}_{5} \mathrm{Me}_{5}\right)$. ATR-IR: $v=2955,2921$, 2868, 2805, 2773, 2726, 1491, 1376, 1258, 1244, 1139, 1097, 1013, 992, 975, 937, 830, 795, 752, 677, 556, 481, 459, $425 \mathrm{~cm}^{-1}$.

$\mathrm{Cp}^{*}(\mathrm{Cl})_{2} \mathrm{Hf}\left[\mathrm{Me}_{3} \mathrm{SiNS}(\mathrm{Me}) \mathrm{NSiMe}_{3}\right] \quad$ 8. Yield: $0.14 \mathrm{~g} \quad(32$ \%). Mp. $215{ }^{\circ} \mathrm{C}$ (dec.). Anal. Found (calcd) for $\mathrm{C}_{17} \mathrm{H}_{36} \mathrm{Cl}_{2} \mathrm{~N}_{2} \mathrm{SSi}_{2} \mathrm{Hf} \quad(606.10 \mathrm{~g} / \mathrm{mol}): \quad \mathrm{C}, 33.50 \quad(33.69) ; \mathrm{H}$, $6.14(6.15) ; \mathrm{N}, 4.69(4.62) ; \mathrm{S}, 5.35(5.29) \% .{ }^{1} \mathrm{H}$ NMR $\left.\left(300 \mathrm{MHz}, \mathrm{THF}-d_{8}, 25{ }^{\circ} \mathrm{C}\right): \delta=0.24(\mathrm{~s}, 18 \mathrm{H}, \quad \mathrm{SiMe})_{3}\right)$, $2.22\left(\mathrm{~s}, 15 \mathrm{H}, \mathrm{C}_{5} \mathrm{Me}_{5}\right), 2.67(\mathrm{~s}, 3 \mathrm{H}, \mathrm{SMe}) .{ }^{13} \mathrm{C} \mathrm{NMR}(75$ $\left.\mathrm{MHz}, \quad \mathrm{THF}-d_{8}, 25{ }^{\circ} \mathrm{C}\right): \delta=1.97 \quad\left(\mathrm{Si} \mathrm{Me}_{3}\right), 13.08(\mathrm{SMe})$, $48.15\left(\mathrm{C}_{5} \mathrm{Me}_{5}\right), 123.70\left(\mathrm{C}_{5} \mathrm{Me}_{5}\right)$. ATR-IR: $\boldsymbol{v}=2957,2908$, 2811, 2124, 2040, 1495, 1437, 1374, 1258, 1244, 1088, $987,938,831,791,751,654,624, \quad 569, \quad 484,449$, 429, $393 \mathrm{~cm}^{-1}$.

Crystal Structure Determination of $1-5$ and 9. Figures 1 to 4 show the diagram of the solid state structures of $1,2,5$ and 9. Crystallographic data of 1 to 5 and 9 are summarized in table S1, selected bond lengths and angles of $3-5$ are given in table 2. The crystals were mounted on nylon loops in inert oil. Data were collected on a AXS D8 Kappa diffractometer with APEX2 detector (MoK $\alpha$ radiation, $\lambda=$ $0.71073 \AA$ A $T=100(1) \mathrm{K})$. The structures were solved by Direct Methods (SHELXS-97) ${ }^{[19]}$ and refined by ful1matrix least-squares on $\mathrm{F}^{2}$. ${ }^{[20]}$ Absorption corrections were performed semi-empirically from equivalent reflections on basis of multi-scans (Bruker AXS APEX2). Al1 non-hydrogen atoms were refined anisotropically, methyl hydrogen atoms as rigid groups and others by a riding mode1 (SHELXL-97/SHELXL-2013). ${ }^{[20]}$

The crystallographic data (without structure factors) were deposited as "supplementary publication no. CCDC-1400389 (1), CCDC-1400390 (2), CCDC-1400391 (3), CCDC-1400392 (4) CCDC-1400393 (5) and CCDC1400394 (9) at the Cambridge Crystallographic Data Centre. These data can be obtained free of charge from The Cambridge Crystallographic Data Centre: CCDC, 12 Union Road, Cambridge, CB21EZ (Fax: (+44)1223/336033; E-mail: deposit@ccdc. cam-ak.uk).

\section{Results and Discussion}

$\mathrm{Me}_{2} \mathrm{Zn}$ and $\mathrm{S}\left(\mathrm{NSiMe}_{3}\right)_{2}$ react with insertion of the sulfurdiimide into the $\mathrm{Zn}-\mathrm{Me}$ bond and subsequent formation of the expected S-methyl-diimidosulfinate

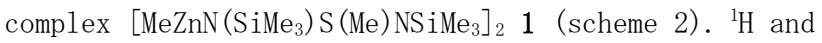
${ }^{13} \mathrm{C}$ NMR spectra of 1 show new characteristic signals due to the S-Me group at $2.83\left({ }^{1} \mathrm{H}\right)$ and $48.1 \mathrm{ppm}\left({ }^{13} \mathrm{C}\right)$, respectively. In contrast, the analogous reaction of $\mathrm{S}\left(\mathrm{NSiMe}_{3}\right)_{2}$ with $\mathrm{Cp}_{2}{ }_{2} \mathrm{Zn}$ yielded a colorless crystalline solid 2 after workup. The ${ }^{1} \mathrm{H}$ and ${ }^{13} \mathrm{C}$ NMR spectra of 2 showed resonances of magnetically inequivalent $\mathrm{SiMe}_{3}$ units but lacked the expected resonances of the $\mathrm{Cp}^{*}$ groups (table 1). In contrast, the ${ }^{1} \mathrm{H}$ NMR spectrum of the raw product (Fig. S. 7) showed resonances of 2 and of decamethy1-1,1'-dihydrofulvalene. Additional peaks between 0 and $0.3 \mathrm{ppm}$ prove the formation of additional, so far unknown, $\mathrm{Me}_{3} \mathrm{Si}-$ containing sideproducts. 


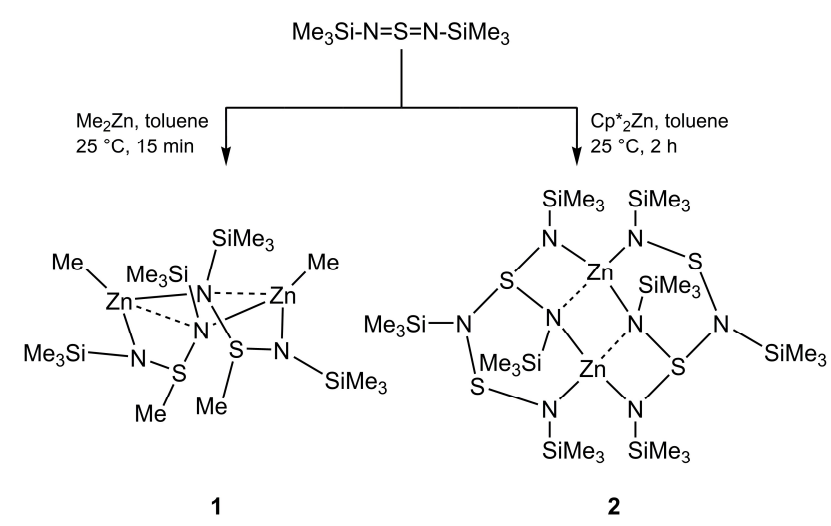

Scheme 2. Synthesis of 1 and 2 by reactions of $\mathrm{S}\left(\mathrm{NSiMe}_{3}\right)_{2}$ with $\mathrm{Me}_{2} \mathrm{Zn}$ and $\mathrm{Cp}_{2}{ }_{2} \mathrm{Zn}$.

Colorless crystals of 1 and 2 were obtained from toluene solutions upon storage at $-30{ }^{\circ} \mathrm{C}$ for 12 hours. 1 crystallizes in the monoclinic space group $P 2_{1} / c$, while 2 crystallizes in the orthorhombic space group Pbca, respectively.

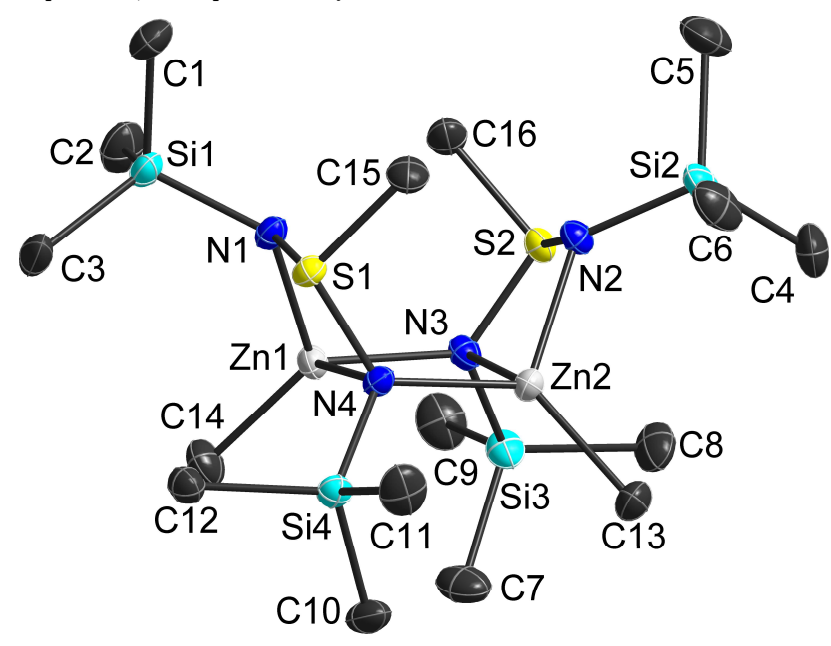

Figure 1. Representation of $\left[\mathrm{MeZnN}\left(\mathrm{SiMe}_{3}\right) \mathrm{S}(\mathrm{Me}) \mathrm{NSiMe}_{3}\right]_{2}$ 1. Thermal ellipsoids are shown at 50\% probability levels. Hydrogen atoms are omitted for clarity. Selected bond lengths $[\AA]$ and angles $\left[{ }^{\circ}\right]$ : Zn1-N1 2. $0472(11), \quad$ Zn1-N3 2.0513(11), Zn1-N4 2.4729(12), Zn2-N2 2.0588(11), Zn2-N3 2. 4626(12), Zn2-N4 2. 0397 (11), S1-N1 1.6141 (12), S1-N4 1.6389(11), S2-N2 1.6134(13), S2-N3 1.6354(11), S1-C15 1.7883(15), S2C16 1.7906 (15); N1-Zn1-N3 114.08(5), N1-Zn1-N4 68. 04 (4), N3-Zn1-N4 93.61(4), N2-Zn2-N3 67.71(4), N2Zn2-N4 112.71(4), N3-Zn2-N4 94.21(4), N1-S1-N4 103. 42 (6), N2-S2-N3 102.91(6), N1-S1-C15 105.34(7), N4-S1-C15 104. 77 (7).

1 forms an eight-membered $\mathrm{N}_{4} \mathrm{~S}_{2} \mathrm{Zn}_{2}$ boat-type conformation ring with threefold-coordinated $\mathrm{S}$ atoms, while the $\mathrm{Zn}$ atoms adopt tetrahedral coordination spheres due to weak transannular $\mathrm{Zn}-\mathrm{N}$ interactions. The $\mathrm{Zn}-\mathrm{N}$ bond lengths therefore differ significantly, with four short (av. 2.0493 $\AA$ ) and two longer transannular $\mathrm{Zn}-\mathrm{N}$ bonds (av. 2.4677 ̊̊), which clearly exceed the sum of the covalent radii $\left(1.98 \AA^{[21]}\right)$ but which are below the sum of the van-der-Waals radii $\left(2.94 \AA^{[22]}\right)$. The $\mathrm{S}-\mathrm{N}$ bond lengths range from $1.6134(13)$ to

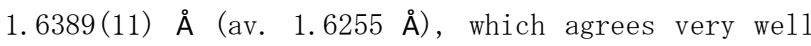
with values previously reported for S-alkyl diimidosulfinate complexes, ${ }^{[23]}$ clearly proving the presence of delocalized $\pi-$ electrons within the $\mathrm{N}-\mathrm{S}-\mathrm{N}$ unit. They are considerably shorter than the S-Me single bonds $(1.7883(15), 1.7906(15) \AA)$. The N-S-N (102.91(6), $\left.\quad 103.42(6)^{\circ}\right)$ and $\mathrm{N}-\mathrm{S}-\mathrm{C}$ bond angles (105.34(7), 104.77(7), 104.75(7), 104.44(7) ${ }^{\circ}$ ) are almost identical.

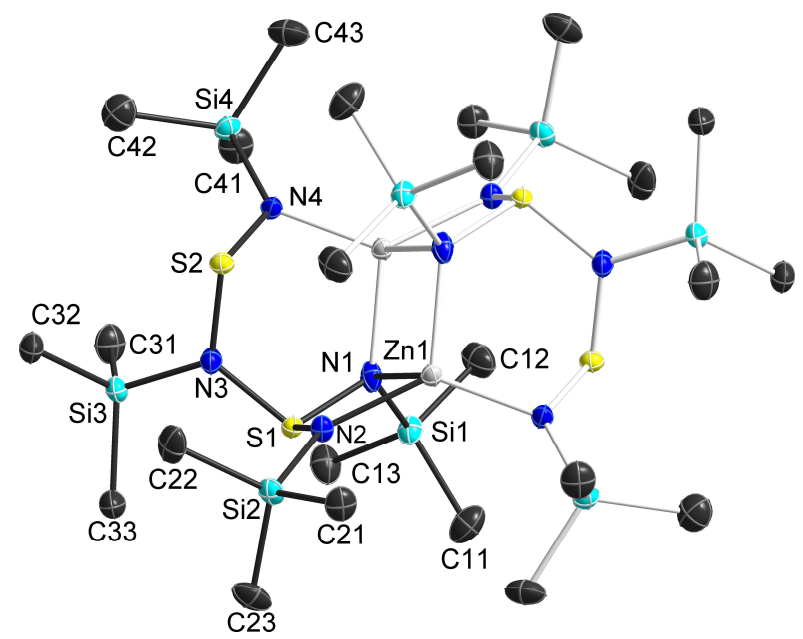

Figure 2. Representation of $\left\{\mathrm{Me}_{3} \mathrm{SiNS}\left[\mathrm{N}\left(\mathrm{SiMe}_{3}\right) \mathrm{SNSiMe}_{3}\right]-\right.$ $\mathrm{N}\left(\mathrm{SiMe}_{3}\right) \mathrm{Zn}_{2}$ 2. Thermal ellipsoids are shown at 50\% probability levels. Hydrogen atoms and second orientation of the disordered parts are omitted for clarity. The part depicted in light bonds is generated via a center of inversion. Selected bond lengths $[\AA]$ and angles $\left[^{\circ}\right]$ : Zn1-N1 2.3229(15), Zn1-N2 1.9793(19), Zn1a-N1 2.0763(16), Zn1a-N4 1.919(2), S1-N1 1.6706 (16), S1-N2 1.6132 (18), S1-N3 1.7006 (16), S2-N3 $1.7125(16), \quad \mathrm{S} 2-\mathrm{N} 41.6703(18) ; \mathrm{N} 1-\mathrm{Zn} 1-\mathrm{N} 2 \quad 71.09(6)^{\circ}$, N1-Zn1a-N4 105. 01 (7), N1-S1-N2 100.05(9), N1-S1-N3 104. $98(8)$, N2-S1-N3 108. 66 (9), N3-S2-N4 106. 49 (8).

The formation of 2 is rather unexpected since the $\mathrm{Cp}^{*}$ ligand isn't transferred to the electrophilic sulfur atom as was observed in the analogous reaction of $\mathrm{ZnMe}_{2}$ as well as in reactions of $\mathrm{Cp}^{*}{ }_{2} \mathrm{Zn}$ with heterocumulenes such as carbodiimides $\mathrm{C}(\mathrm{NR})_{2}, \mathrm{CO}_{2}, \mathrm{CS}_{2}$ and several isocyanates RNCO. ${ }^{[24]}$ Instead, two $\mathrm{Zn}-\mathrm{Cp}^{*}$ bond breakage reactions as well as a dimerization of two sulfurdiimide molecules has occurred, which can also described as transimidation reaction with subsequent oxidation of $\mathrm{S}(\mathrm{IV})$ to $\mathrm{S}(\mathrm{VI})$. One sulfurdiimide molecule connects through a nucleophilic $\mathrm{N}$ atom to the electrophilic sulfur atom of a second sulfurdiimide molecule, resulting in the formation of a $\left(\mathrm{Me}_{3} \mathrm{SiN}\right)_{2} \mathrm{SN}\left(\mathrm{SiMe}_{3}\right) \mathrm{SN}\left(\mathrm{SiMe}_{3}\right)$ unit, which asymmetrically coordinates (Zn1-N2 1.9793(19) Å, Zn1a-N1 2.0763 (16) $\AA$ ) as bridging diimidosulfinate to two zinc atoms. The additional NSN unit serves as pendant donor sidearm and coordinates to the second zinc atom (Zn1a-N4 1.919(2) Å). In addition, Zn1 shows a fourth 
(trans-annular) Zn1-N1 bond, which is slightly shorter $(2.3229(15) \AA)$ compared to the transannular $\mathrm{Zn}-\mathrm{N}$ bond lengths observed in 1. Slightly comparable diimidosulfinate ligands containing a pendent donorarm have been reported by Stalke et al., ${ }^{[6 b]}$ which also reported on the reaction of a sterically hindered diazasulfite with N, N'-di-(tert-buty1)sulfur diimide, which occurred with addition of the negatively charged nitrogen atom to the electrophilic sulfur atom and subsequent formation of a triazasulfite (transimidation). ${ }^{[25]}$ Alternatively, the structure of 2 can be described as an eight membered $\mathrm{N}_{4} \mathrm{~S}_{2} \mathrm{Zn}_{2}$ ring as was observed for 1 , which adopts a chair-type conformation resulting from the crystallographic centro-symmetry. In contrast to 1 , the $\mathrm{Zn}-\mathrm{N}$ bond distances in 2 differ by almost $0.16 \AA$ (1.919(2) - 2.0763(16) $\AA$ ) and the S-N bond lengths also span a much wider range $(\mathrm{S} 1-\mathrm{N} 2 \quad 1.6132(18) \quad \AA, \quad \mathrm{S} 1-\mathrm{N} 1$ $1.6706(16) \quad \AA, \quad \mathrm{S} 2-\mathrm{N} 4 \quad 1.6703(18) \AA ̊ \quad \mathrm{~S} 1-\mathrm{N} 3 \quad 1.7006$ (16) $\AA$, S2-N3 1.7125(16) ̊). The short S1-N2 bond points to rather localized $\pi$-electrons within in the $\mathrm{S} 1-\mathrm{N} 2$ bond, while the other $\mathrm{S}-\mathrm{N}$ bonds are slightly elongated compared to those observed in 1. The N11-Zn1-N2 $\left(71.09(6)^{\circ}\right)$ and $\mathrm{N} 1-\mathrm{S} 1-\mathrm{N} 2\left(100.05(9)^{\circ}\right)$ bond angles of the bridging diimidosulfinate moiety in 2 are significantly smaller than the N1-Zn1a-N4 (105.01(7) ${ }^{\circ}$ and N3-S2-N4 $\left(106.49(8)^{\circ}\right)$ bond angles of the six-membered ring.

In order to prove if sulfurdiimides also react with early transition metal complexes with insertion into metal carbon bonds, $\mathrm{S}\left(\mathrm{NSiMe}_{3}\right)_{2}$ was treated with $\mathrm{Cp}^{*} \mathrm{MMe}_{3}(\mathrm{M}=\mathrm{Ti}, \mathrm{Zr}, \mathrm{Hf})$. The reactions smoothly proceeded with formation of the expected S-methyldiimidosulfinate complexes of the general type $\left.\mathrm{Cp}^{*}(\mathrm{Me})_{2} \mathrm{M}_{\mathrm{Me}} \mathrm{SiNS}(\mathrm{Me}) \mathrm{NSiMe}_{3}\right] \quad(\mathrm{M}=\mathrm{Ti} 3, \mathrm{Zr} 4$, Hf 5) as was proven by ${ }^{1} \mathrm{H}$ and ${ }^{13} \mathrm{C}$ NMR spectroscopy. In addition, the corresponding dichloride complexes $\left.\mathrm{Cp}^{*}(\mathrm{Cl})_{2} \mathrm{M}^{2} \mathrm{Me}_{3} \mathrm{SiNS}(\mathrm{Me}) \mathrm{NSiMe}_{3}\right] \quad(\mathrm{M}=\mathrm{Ti} 6, \quad \mathrm{Zr}$ 7, Hf 8) were obtained from reactions of either isolated or in situ generated lithium S-methyl-diimidosulfinate $\left[\left(\mathrm{Me}_{3} \mathrm{SiN}\right)_{2} \mathrm{~S}(\mathrm{Me}) \mathrm{Li}(\mathrm{thf})\right]_{2} 9$ with equimolar amounts of $\mathrm{Cp}^{*} \mathrm{MCl}_{3}$ (scheme 3). However, while $3-5$ and 9 are typically formed in excellent yields of $90 \%$ and higher, $6-8$ were only isolated in roughly $30 \%$ after workup. Fig S 17 exemplarily shows a raw spectrum ( ${ }^{1} \mathrm{H}$ NMR) of the reaction product obtain from the reaction of 9 with $\mathrm{Cp}^{*} \mathrm{TiCl}_{3}$. Aside from the peaks that can be addressed to 6 , additional peaks are observable, which clearly prove the formation of additional side-products. $6-8$ could be isolated from these mixtures by recrystallization from solutions in thf. Unfortunately, any attempt to isolate and identify the additional reaction products failed, to date. 3 5 are soluble in almost every non-coordinating (pentane, hexane, toluene) and coordinating solvent (Et ${ }_{2} \mathrm{O}$, THF), while $6-8$ are only soluble in THF. ${ }^{1} \mathrm{H}$ NMR spectra of $3-8$ each show a single resonances of the $\mathrm{Cp}^{*}$ group, indicating a $\eta^{5}$-binding mode, as well as single resonances of the M-Me $(3-5)$, S-Me and $\mathrm{SiMe}_{3}$ groups (table 1).

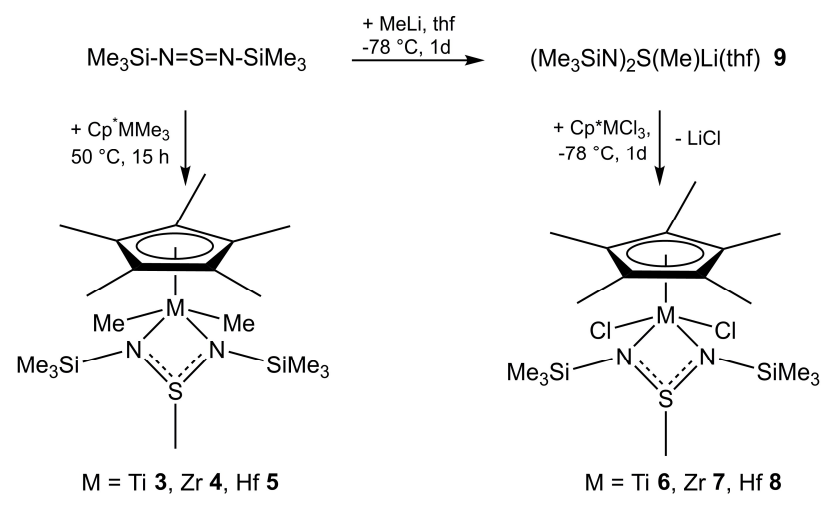

Scheme 3. Synthesis of $3-8$.

( (Table 1 here $)$ )

Colorless crystals of 3,4 and 5 were obtained from concentrated solutions in toluene after storage at 18 ${ }^{\circ} \mathrm{C}$ for 12 hours. 3 to 5 crystallize in the monoclinic space group $P 2_{1} / n$. Even though the unit cell lengths are almost the same, $\boldsymbol{B}$ in 3 differs by roughly $10^{\circ}$ from $B$ in 4 and 5 . Consequently, 4 and 5 may be considered as isostructural, but the molecular conformation of $3-5$ is very similar. Figure 3 shows the molecular structure of 5 , while central bonding parameters are summarized in table 2.

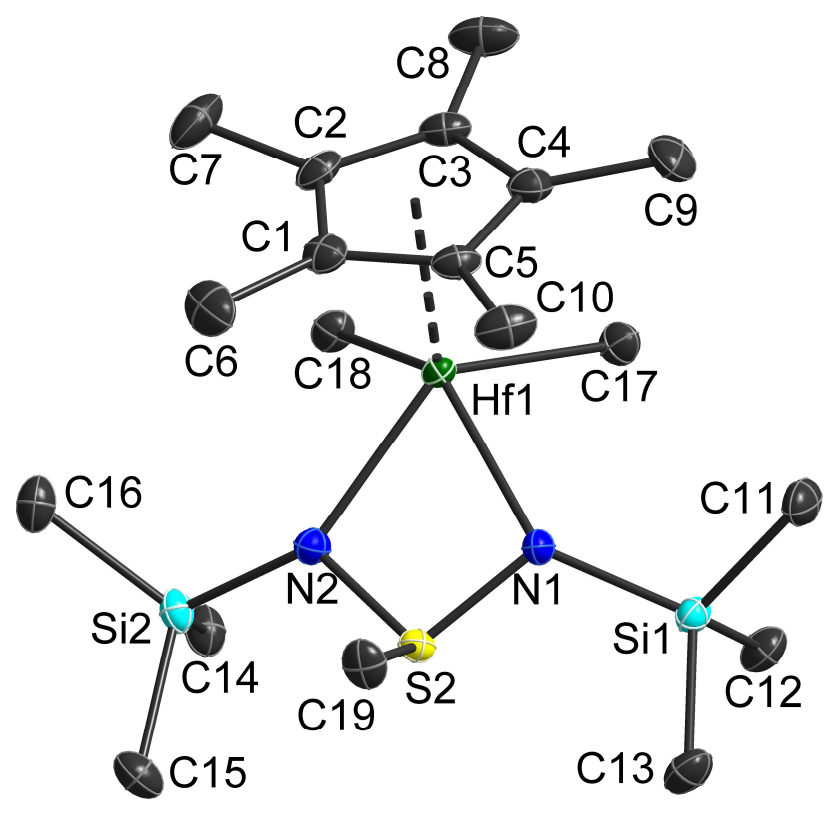

Figure $3 . \quad$ Representation of $\mathrm{Cp}^{*}(\mathrm{Me})_{2} \mathrm{Hf}\left[\mathrm{Me}_{3} \mathrm{SiNS}(\mathrm{Me}) \mathrm{NSiMe}_{3}\right]$ 5. Thermal ellipsoids are shown at $50 \%$ probability levels. Hydrogen atoms are omitted for clarity.

The $\mathrm{Ti}-\mathrm{N}$ and $\mathrm{Ti}-\mathrm{C}$ bond lengths are shorter than the corresponding values of the higher homologues 4 and 5 (see table 2). The S-methyl-diimidosulfinate ligand coordinates to the group 4 metal center in a chelating binding mode and the $\mathrm{Cp}^{*}$ units are $\eta^{5}$-bonded as 
was expected from the NMR studies. The resulting coordination geometry around the central metal atom can be described as distorted tetragonal pyramid ( $\mathrm{Cp}^{*}$ represented by its centroid). The $\mathrm{Cp}^{*}{ }_{\text {centr. }}-\mathrm{M}$ bond lengths ( (2.0871 $\AA 3,2.2332 \AA 4,2.2160 \AA$ 5) ) as well as the $\mathrm{M}-\mathrm{N}$ bond lengths $(2.1420(11) \AA$, $2.1586(10) \quad \AA \quad 3 ; 2.2656(16)$ A, $2.2780(16)$ A 4 ; $2.2417(16) \AA$, $2.2588(15) \AA 5)$ of 3 are significantly shorter compared to those of 4 and 5 , which are almost identical as is typical for group 4 metal complexes. In contrast, the $\mathrm{S}-\mathrm{N}$ bond lengths and $\mathrm{N}-\mathrm{S}-\mathrm{N}$ bond angles of $3-5$ are almost identical, while the N1-Ti1-N2 bond angle $\left(69.41(41)^{\circ}\right)$ is slightly smaller than those of the heavier congeners $\left(65.68(6)^{\circ} 4\right.$, $\left.66.19(5)^{\circ} 5\right)$, respectively.

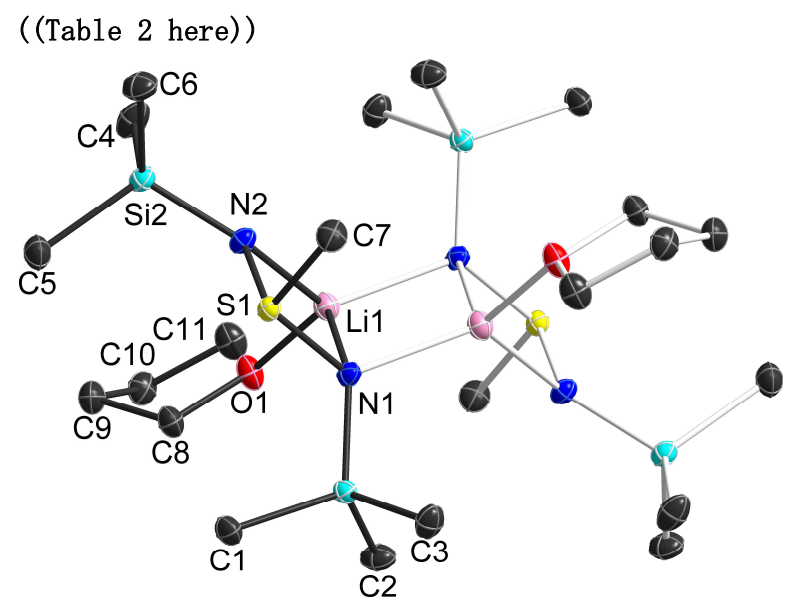

Figure 4. Representation of $\left[\left(\mathrm{Me}_{3} \mathrm{SiN}\right)_{2} \mathrm{~S}(\mathrm{Me}) \mathrm{Li}(\mathrm{thf})\right]_{2}$ 9. Thermal ellipsoids are shown at 50\% probability levels. Hydrogen atoms are omitted for clarity. The part depicted in light bonds is generated via a center of inversion.

Colorless crystals of 9 were obtained from a concentrated solution in THF after storage at $-30{ }^{\circ} \mathrm{C}$ for 12 hours. 9 crystallizes in the triclinic space group $P-1$ as a centrosymmetric dimer and its structure is shown in figure 4. Even though the S-methy1diimidosulfinate ligands in 1 and 9 adopt bridging positions, both structures differ significantly. 1 adopts a boat-type conformation in which the Smethyl-diimidosulfinate ligand shows a symmetrical bridging mode with almost identical $\mathrm{Zn}-\mathrm{N}$ bond lengths, while 9 adopts a chair-type conformation and the S-methyl-diimidosulfinate ligand coordinates in a rather asymmetric bridging binding mode between two Li metals with significantly different $\mathrm{Li}-\mathrm{N}$ bond lengths (Li1-N2 2.0390(18) Å, Li1-N1a 2.0906(18) ̊̊). In addition, the transannular Li-N bonds in 9 (Li1-N1 $2.1800(17) \AA ̊)$ are significantly shorter compared to the transannular $\mathrm{Zn}-\mathrm{N}$ bonds in 1 (Zn1-N4 2. 4729(12) $\AA$, $\quad \mathrm{Zn} 2-\mathrm{N} 3 \quad 2.4626(12) \AA ̊$ ). As a consequence, the structure of 9 can alternatively be described as a ladder-type structure with three edge-shared fourmembered rings. An additionally coordinated thf molecule results in the coordination number 4 for each $\mathrm{Li}$ cation, which consequently adopt distorted tetrahedral coordination spheres. The N1-Li1-N2 bond angle $\left(73.94(6)^{\circ}\right)$ is significantly smaller than the N1-Li1N1a $\left(103.21(7)^{\circ}\right)$ and N2-Li1-N1a $\left(122.88(8)^{\circ}\right)$ bond angles. The $\mathrm{S}-\mathrm{N}$ bond length of the fourfold coordinated $\mathrm{N}$ atom is slightly elongated (S1-N1 1.6202(8) $\AA$ A, S1-N2 $1.6039(8) \AA$ A $)$, but both values prove the formation of delocalized $\pi$-electrons within the $\mathrm{S}^{-}$ methyl-diimidosulfinate unit. The $\mathrm{N}-\mathrm{S}-\mathrm{N}$ bond angle of 103. $94(4)^{\circ}$ in 9 is almost identical to that observed in 1 , but wider than those in $3-5$, respectively. Comparable ladder-type structures have been reported for $\mathrm{Li}^{-}$and $\mathrm{K}$-diimidosulfinates. ${ }^{[5 \mathrm{a}, 6 \mathrm{a}, 6 \mathrm{~d}, 25,26]}$

Conclusion. $\mathrm{S}\left(\mathrm{NSiMe}_{3}\right)_{2}$ reacts with $\mathrm{Me}_{2} \mathrm{Zn}, \mathrm{Cp}^{*} \mathrm{MMe}_{3}$ (M $=\mathrm{Ti}, \mathrm{Zr}$, Hf) and MeLi with insertion into the metalcarbon bond and formation of dimeric S-methyl diimidosulfinate complexes $\left[\mathrm{MeZnN}\left(\mathrm{SiMe}_{3}\right) \mathrm{S}(\mathrm{Me}) \mathrm{NSiMe}_{3}\right]_{2}$ 1 and $\left[\left(\mathrm{Me}_{3} \mathrm{Si}\right)_{2} \mathrm{~N}_{2} \mathrm{~S}(\mathrm{Me}) \mathrm{Li}(\mathrm{thf})\right]_{2} \quad 9$ with bridging diimidosulfinate ligands or monomeric complexes of the type $\mathrm{Cp}^{*}(\mathrm{Me})_{2} \mathrm{M}\left[\mathrm{Me}_{3} \mathrm{SiNS}(\mathrm{Me}) \mathrm{NSiMe}_{3}\right](\mathrm{M}=\mathrm{Ti} 3, \mathrm{Zr} 4$, Hf 5) with chelating diimidosulfinate ligands. In contrast, the reaction of $\mathrm{Cp}^{*}{ }_{2} \mathrm{Zn}$ unexpectedly occurred with transimidation, yielding the complex

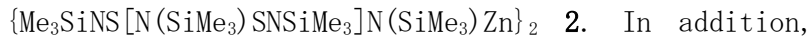
salt elimination reactions of 9 with $\mathrm{Cp}^{*} \mathrm{MCl}_{3}$ proceeded with formation of the expected complexes $\mathrm{Cp}^{*}(\mathrm{Cl})_{2} \mathrm{M}\left[\mathrm{Me}_{3} \mathrm{SiNS}(\mathrm{Me}) \mathrm{NSiMe}_{3}\right](\mathrm{M}=\mathrm{Ti}$ 6, Zr 7, Hf 8).

\section{ASSOCIATED CONTENT}

\section{Supporting Information}

CIF files giving crystallographic data for $1-5$ and 9, a table giving crystallographic details of $1-5$ and 9 (Table S1) and figures of the solid state structures of 3 (Fig. S29) and 4 (Fig. S30), as we11 as ${ }^{1} \mathrm{H}$ and ${ }^{13} \mathrm{C}$ NMR and IR spectra of $1-9$ (Fig. S1 S28). This material is available free of charge via the Internet at http://pubs. acs. org.

\section{AUTHOR INFORMATION}

\section{Corresponding Author}

S. S. : te1, +49 0201-1834635; fax, + 49 0201-1833830; e-mail, stephan.schulz@uni-due.de.

\section{Author Contributions}

The manuscript was written through contributions of all authors. All authors have given approval to the final version of the manuscript.

The authors declare no competing financial interest.

\section{ACKNOWLEDGMENT}

Stephan Schulz gratefully acknowledges financial support by the University of Duisburg-Essen.

\section{REFERENCES}

(1) See the following and reference cited therein: a) Fleischer, R. Stalke, D. Coord. Chem. Rev. 1998, 176, 431450; b) Stalke, D. Chem. Commun. 2012, 48, 9559-9573; c) Chivers, T. Chem. Rev. 1985, 85, 341-365; b) Brask, J. K. ; 
Chivers, T. Angew. Chem. 2001, 113, 4082-4098, Angew. Chem. Int. Ed. 2001, 40, 3960-3976.

(2) Lubben, T. V. ; Wolczanski, P. T. ; van Duyne, G. D. Organometallics 1984, 3, 977-983.

(3) a) Lisovskii, A. Eisen, M. S. in Living and Controled Polymerization (Ed. J. Jagur-Grodzinski), Ch. 10, pp 343376; b) Smolensky E. ; Eisen, M. S. Dalton Trans. 2007, 5623-5650.

(4) a) Hänssgen, D. ; Steffens, R. J. Organomet. Chem. 1982, 236, 53-60; b) Hänssgen, D. ; Steffens, R. Z. Naturforsch. 1985, 40b, 919-922.

(5) a) Pauer, F. ; Stalke, D. J. Organomet. Chem. 1991, 418, 127-145; b) Pauer, F. ; Rocha, J. ; Stalke, D. Chem. Commun. 1991, 1477-1479; c) Freitag, S. ; Kolodziejski, W. Pauer, F. ; Stalke, D. Dalton Trans. 1993, 3479-3488.

(6) a) Meinholz, M. M. ; Stalke, D. Z. Anorg. Allg. Chem. 2011, 637, 2233-2238; b) Meinholz, M. M. ; Pandey, S. K. ; Deuerlein, S. M. ; Stalke, D. Dalton Trans. 2011, 40, 16621671; c) Meinholz, M. M. ; Stalke, D. Eur. J. Inorg. Chem. 2011, 29, 4578-4584; d) Meinholz, M. M. ; Klemmer, M. ; Kriemen, E. ; Stalke, D. Chem. Eur. J. 2011, 17, 9415-9422.

(7) a) Schulz, T. ; Stalke, D. Z. Naturforsch. 2010, 65b, 701-710; b) Schulz, T. ; Dauer, D. -R. ; Stalke, D. Z. Naturforsch. 2010, 65b, 711-718.

(8) Schulz, T. ; Deuerlein, S. ; Stalke D. Eur. J. Inorg. Chem. 2010, 2178-2184.

(9) Fleischer, R. ; Stalke, D. J. Organomet. Chem. 1998, 550, 173-182.

(10) See for instance: a) Knösel, F. ; Noltemeyer, M. ; Edelmann, F. T. Z. Naturforsch. 1989, 44b, 1171-1174; b) Roesky, H. W. ; Grünhagen, A. ; Edelmann, F. T. ; Noltemeyer, M. Z. Naturforsch. 1989, 44b, 1365-1368; c) Meinholz, M. M. ; Stalke D. Z. Naturforsch. 2011, 66b, 981-984; d) Selinka, C. ; Deuerlein, S. ; Häuser, T. ; Stalke, D. Inorg. Chim. Acta 2004, 357, 1873-1880.

(11) a) Roesky, H. W. ; Schmidt, H. -G. ; Noltemeyer, M. ; Sheldrick, G. M. Chem. Ber. 1983, 116, 1411-1414; b) Haas, A. ; Wingender, N. Z. Anorg. Allg. Chem. 1989, 576, 151-159; c) Kottmair-Maieron, D. ; Lechler, R. ; Weidlein, J. Z. Anorg. Allg. Chem. 1991, 593, 111-123; d) Hasselbring, R. ; Leichtweis, I. ; Noltemeyer, M. ; Roesky, H. W. ; Schmidt, H. G. ; Herzog, A. Z. Anorg. Allg. Chem. 1993, 619, 1543-1550; e) Hubrich, C. ; Schulz, A. ; Villinger, A. Z. Anorg. Allg. Chem. 2007, 633, 2362-2366.

(12) Gehrmann, T. ; Kruck, M. ; Wadepoh1, H. ; Gade, L. H. Chem. Commun. 2012, 48, 2397-2398.

(13) Kaleta, K. ; Kessler, M. ; Beweries, T. ; Arndt, P. ; Spannenberg, A. ; Rosenthal, U. Eur. J. Inorg. Chem. 2012, 3388-3393.

(14) Kaleta, K. ; Ruhmann, M. ; Theilmann, 0. ; Roy, S. ; Beweries, T. ; Arndt, P. ; Villinger, A. ; Jemmis, E. D.; Schulz, A. ; Rosenthal, U. Eur. J. Inorg. Chem. 2012, 611617.

(15) Walfort, B. ; Leedham, A. P. ; Russe11, C. A. ; Stalke, D. Inorg. Chem. 2001, 40, 5668-5674.

(16) a) Scheiper, C. ; Naglav, D. ; Bläser, D. ; Wölper, C. ; Schulz, S. Z. Anorg. Allg. Chem. 2015, 641, 871-875; b) Gondzik, S. ; Bläser, D. ; Wölper, C. ; Schulz, S. J. Organomet. Chem. 2015, 783, 92-95; c) Scheiper, C. ; Wölper, C. ; Bläser, D. ; Roll, J. ; Schulz, S. Z. Naturforsch. 2014, 69b, 1365-1374; d) Schulz, S. ; Bayram, M. ; Bläser, D. ; Wölper C. Organometallics 2014, 33, 2080-2087; e) Scheiper, C. ; Dit- trich, D. ; Wölper, C. ; Bläser, D. ; Roll, J. ; Schulz, S. Eur. J. Inorg. Chem. 2014, 2230-2240; f) Gutschank, B. ; Schulz, S. ; Bläser, D. ; Wölper C. J. Chem. Soc., Dalton Trans. 2014, 43, 2907-2914; g) Gutschank, B. ; Bayram, M. ; Schulz, S. ; Bläser, D. ; Wölper, C. Eur. J. Inorg. Chem. 2013, 5495-5502; h) Scheiper, C. ; Schulz, S. ; Wölper, C. ; Bläser, D. ; Roll, J. Z. Anorg. Allg. Chem. 2013, 639, 11531159; i) Gutschank, B. ; Schulz, S. ; Marcinkowski, M. ; Jansen, G. ; Bandmann, H. ; Bläser, D. ; Wölper, C. Angew. Chem. 2012, 124, 11051-11055, Angew. Chem. Int. Ed. 2012, 51, 10893-10897; j) Bendt, G. ; Schulz, S. ; Spielmann, J. ; Schmidt, S. ; Bläser, D. ; Wölper, C. Eur. J. Inorg. Chem. 2012, 3725-3731; k) Schmidt, S. ; Gutschank, B. ; Schulz, S. ; Bläser, D. ; Boese, R. ; Wölper, C. Eur. J. Inorg. Chem. 2011, 4464-4470; 1) Schmidt, S. ; Schulz, S. ; Bläser, D. ; Boese, R. ; Bolte, M. Organometallics 2010, 29, 6097-6103; m) Gutschank, B. ; Schulz, S. ; Bläser, D. ; Boese, R. ; Wölper, C. Organometallics 2010, 29, 6133-6136; n) Schulz, S. ; Eisenmann, T. ; Schmidt, S. ; Bläser, D. ; Westphal, U. ; Boese, R. Chem. Commun. 2010, 46, 7226-7228; o) Gutschank, B. ; Schulz, S. ; Westphal, U. ; Bläser, D. ; Boese, R. Organometallics 2010, 29, 2093-2097.

(17) Warrens, C. P. ; Woollins J. D. ; Witt M. ; Roesky H. W. Inorg. Syntheses 1989, 25, 43-47.

(18) Blom, R. ; Boersma, J. ; Budzelaar, P. H. M. ; Fischer, B. ; Haaland, A. ; Volden, H. V. ; Weidlein, W. Acta Chem. Stand. A 1986, 40, 113-120.

(19) Mena, M. ; Royo, P. ; Serrano, R. Organometallics $1989,8,476-482$.

(20) Llinás, G. H. ; Mena, M. ; Palacios, F. ; Royo, P. ; Serrano, R. J. Organomet. Chem. 1988, 340, 37-40.

(21) SHELXS-97, Sheldrick, G. M. Acta Crystallogr. Sect. A 1990, 46, 467-473.

(22) SHELXL-97, Program for Crystal Structure Refinement, Sheldrick, G. M. ; Universität Göttingen, 1997. See also: Sheldrick, G. M. Acta Crystallogr. Sect. A 2008, 64, 112128.

(23) Pyykkö, P. ; Atsumi, M. Chem. Eur. J. 2009, 15, 186197.

(24) Bondi, A. J. Phys. Chem. 1964, 68, 441-451.

(25) A search for $\mathrm{C}-\mathrm{S}\left({ }^{-\mathrm{N}}\right) \mathrm{\cdots}_{\mathrm{N}} \cdots \mathrm{M}$ with the number of atoms bonded to $\mathrm{S}$ set to three yielded 24 hits which included 144 $\mathrm{S}-\mathrm{N}$ bonds. The bond lengths range from $1.569 \AA$ to $1.687 \AA$ with a mean value of $1.631(17) \AA$. Cambridge Structural Database, Version 5.36, see also: Allen, F. H. Acta Cryst. 2002, B58, 380-388.

(26) Schmidt, S. ; Schäper, R. Schulz, S. ; Bläser, D. ; Wölper, C. Organometallics 2011, 30, 1073-1078; Schulz, S. ; Schmidt, S. ; Bläser, D. ; Wölper, C. Eur. J. Inorg. Chem. 2011, 27, 4157-4160; Schulz, S. ; Schmidt, S. ; B1äser, D. ; Wölper, C. Z. Anorg. Allg. Chem. 2012, 638, 1705-1710.

(27) Walfort, B. ; Bertermann, R. ; Stalke, D. Chem.-Eur. J. 2001, 7, 1424-1430.

(28) a) Wrackmeyer, B. ; Klaus, U. ; Milius, W. Inorg. Chim. Acta 1996, 250, 327; b) Edelmann, F. T.; Knösel, F. ; Pauer, F. ; Stalke, D. ; Bauer, W. J. Organomet. Chem. 1991, 438, 1-10; c) Meyer, J. T. E. ; Schultz, T. ; Pandey, S. K. ; Stalke, D. Inorg. Chem. 2010, 49, 2743-2749; d) Chivers, T. ; Edwards, M. ; Hilts, R. W. ; Parvez M. ; Vollmerhaus, R. Chem. Commun. 1993, 1483-1485. 
Table 1. ${ }^{1} \mathrm{H}$ and ${ }^{13} \mathrm{C}$ NMR chemical shifts of $1-5$ and $9\left(\mathrm{C}_{6} \mathrm{D}_{6}, 300 \mathrm{MHz}, 25{ }^{\circ} \mathrm{C}\right)$ and $6-8\left(\mathrm{THF}-d_{8}, 300 \mathrm{MHz}\right.$, $25^{\circ}$ C) in ppm.

\begin{tabular}{|c|c|c|c|c|c|c|c|c|}
\hline \multirow[t]{2}{*}{ Compound } & \multicolumn{2}{|c|}{ MMe } & \multicolumn{2}{|c|}{$\mathrm{NSiMe}_{3}$} & \multicolumn{2}{|c|}{ SMe } & \multicolumn{2}{|c|}{ Cp* } \\
\hline & ${ }^{1} \mathrm{H}$ & ${ }^{13} \mathrm{C}$ & ${ }^{1} \mathrm{H}$ & ${ }^{13} \mathrm{C}$ & ${ }^{1} \mathrm{H}$ & ${ }^{13} \mathrm{C}$ & ${ }^{1} \mathrm{H}$ & ${ }^{13} \mathrm{C}$ \\
\hline 1 & -0.30 & -5.27 & 0.23 & 1.99 & 2.83 & 48.09 & - & - \\
\hline 2 & - & - & $\begin{array}{c}0.21, \\
0.42, \\
0.44, \quad 0.57\end{array}$ & $\begin{array}{c}0.89, \\
2.10, \\
2.34,3.01\end{array}$ & - & - & - & - \\
\hline 3 & 0.63 & 13.30 & 0.24 & 2.68 & 1.94 & 48.80 & 2.05 & $\begin{array}{l}65.25 \\
123.26\end{array}$ \\
\hline 4 & 0.28 & 12.50 & 0.19 & 2.40 & 2.02 & 46.14 & 2.09 & $\begin{array}{l}50.90 \\
119.85\end{array}$ \\
\hline 5 & 0.05 & 12.39 & 0.18 & 2.40 & 2.06 & 53.28 & 2.06 & $\begin{array}{l}67.83, \\
118.83\end{array}$ \\
\hline 6 & - & - & 0.25 & 1. 19 & 2.78 & 12.68 & 2.08 & $\begin{array}{l}\text { 44. } 64 \\
125.38\end{array}$ \\
\hline 7 & - & - & 0.24 & 1.94 & 2.70 & 13. 39 & 2.17 & $\begin{array}{l}\text { 48. } 31 \\
125.91\end{array}$ \\
\hline 8 & - & - & 0.24 & 1.97 & 2.67 & 13. 08 & 2.22 & $\begin{array}{l}48.15 \\
123.70\end{array}$ \\
\hline 9 & - & - & 0.34 & 2.64 & 2.24 & 53. 49 & - & - \\
\hline
\end{tabular}

Table 2. Selected bond lengths $[\AA]$ and angles $\left[^{\circ}\right]$ of $3,4,5$ and 9.

\begin{tabular}{|c|c|c|c|c|}
\hline & 3 & 4 & 5 & 9 \\
\hline $\mathrm{M}-\mathrm{N}$ & $\begin{array}{c}2.1420(11), \\
2.1586(10)\end{array}$ & $\begin{array}{c}2.2656(16), \\
2.2780(16)\end{array}$ & $\begin{array}{l}2.2417(16), \\
2.2588(15)\end{array}$ & $\begin{array}{c}2.1800(17), \\
2.0390(18)\end{array}$ \\
\hline$M^{\prime}-\mathrm{N}$ & - & - & - & 2. $0906(18)$ \\
\hline $\mathrm{S}-\mathrm{N}$ & $\begin{array}{l}1.6220(11), \\
1.6227(10)\end{array}$ & $\begin{array}{c}1.6214(17), \\
1.6253(16)\end{array}$ & $\begin{array}{l}1.6254(16), \\
1.6284(16)\end{array}$ & $1.6202(8), \quad 1.6039(8)$ \\
\hline $\mathrm{M}-\mathrm{Me}$ & $\begin{array}{l}2.1440(13) \\
2.1537(13)\end{array}$ & $2.270(2), \quad 2.2801(19)$ & $2.250(2), \quad 2.2641(19)$ & - \\
\hline $\mathrm{M}-\mathrm{Cp} *^{[\mathrm{a}]}$ & 2. 0871 & 2. 2332 & 2.2160 & - \\
\hline $\mathrm{S}-\mathrm{C}$ & 1. $8018(14)$ & $1.802(9)$ & 1. $797(2)$ & 1. $8027(10)$ \\
\hline $\mathrm{N}-\mathrm{S}-\mathrm{N}$ & $97.99(5)$ & $98.75(8)$ & $98.10(8)$ & $103.94(4)$ \\
\hline $\mathrm{N}-\mathrm{M}-\mathrm{N}$ & $69.41(4)$ & $65.68(6)$ & $66.19(5)$ & $73.94(6), \quad 103.21(7)$ \\
\hline $\mathrm{M}-\mathrm{N}-\mathrm{M}$ & - & - & - & $76.79(7)$ \\
\hline $\mathrm{N}-\mathrm{M}-\mathrm{Me}$ & $\begin{array}{l}84.86(5), \quad 85.71(5) \\
129.19(5), \quad 133.16(5)\end{array}$ & $\begin{array}{c}85.04(7), \quad 86.11(7), \\
128.32(7), \quad 133.68(7)\end{array}$ & $\begin{array}{ll}84.70(6), & 85.69(7) \\
28.15(7), & 133.75(6)\end{array}$ & - \\
\hline $\mathrm{Me}-\mathrm{M}-\mathrm{Me}$ & $81.23(5)$ & $85.29(7)$ & $85.42(7)$ & - \\
\hline $\mathrm{Cp} *-\mathrm{M}-\mathrm{Me}$ & $108.01, \quad 109.82$ & 106. $33,106.85$ & $107.18, \quad 107.79$ & - \\
\hline $\mathrm{Cp} *-\mathrm{M}-\mathrm{N}$ & $118.73, \quad 120.96$ & $119.72, \quad 124.59$ & $118.76, \quad 123.76$ & - \\
\hline
\end{tabular}

[a] $\mathrm{Cp}^{*}$ refers to the centroid of the $\mathrm{C}_{5}-$ ring of the $\mathrm{Cp}^{*}$ ligand. Since the centroid's position is constrained to the positions of the $\mathrm{C}$ atoms no standard uncertainty can be given. 
Reactions of equimolar amounts of $\mathrm{Me}_{2} \mathrm{Zn}$ and $\mathrm{S}\left(\mathrm{NSiMe}_{3}\right)_{2}$ yielded the expected S-methyl diimidosulfinate $\left[\mathrm{MeZnN}\left(\mathrm{SiMe}_{3}\right) \mathrm{S}(\mathrm{Me}) \mathrm{NSiMe}_{3}\right]_{2}$ 1, while the analogous reaction with $\mathrm{Cp}_{2}{ }_{2} \mathrm{Zn}$ gave the unexpected complex $\left\{\mathrm{Me}_{3} \mathrm{SiNS}\left[\mathrm{N}\left(\mathrm{SiMe}_{3}\right) \mathrm{SNSiMe}_{3}\right] \mathrm{N}\left(\mathrm{SiMe}_{3}\right) \mathrm{Zn}_{2}{ }_{2}\right.$ 2. Insertion reactions of $\mathrm{S}\left(\mathrm{NSiMe}_{3}\right)_{2}$ with $\mathrm{Cp}^{*} \mathrm{MMe}_{3}$ yielded $\mathrm{Cp}^{*}(\mathrm{Me})_{2} \mathrm{M}\left[\mathrm{Me}_{3} \mathrm{SiNS}(\mathrm{Me}) \mathrm{NSiMe}_{3}\right] \quad(\mathrm{M}=\mathrm{Ti} 3, \mathrm{Zr}$ 4, Hf 5), while the corresponding Cl-substituted derivatives $\mathrm{Cp}^{*}(\mathrm{Cl})_{2} \mathrm{M}_{2}\left[\mathrm{Me}_{3} \mathrm{SiNS}(\mathrm{Me}) \mathrm{NSiMe}_{3}\right] \quad(\mathrm{M}=\mathrm{Ti}$, $\mathrm{Zr}$ 7, Hf 8) were obtained from salt elimination reactions of Li S-methyl diimidosulfinate $\left[\left(\mathrm{Me}_{3} \mathrm{Si}\right)_{2} \mathrm{~N}_{2} \mathrm{~S}(\mathrm{Me}) \mathrm{Li}(\mathrm{thf})\right]_{2} 9$ with $\mathrm{Cp}^{*} \mathrm{MCl}_{3}$.

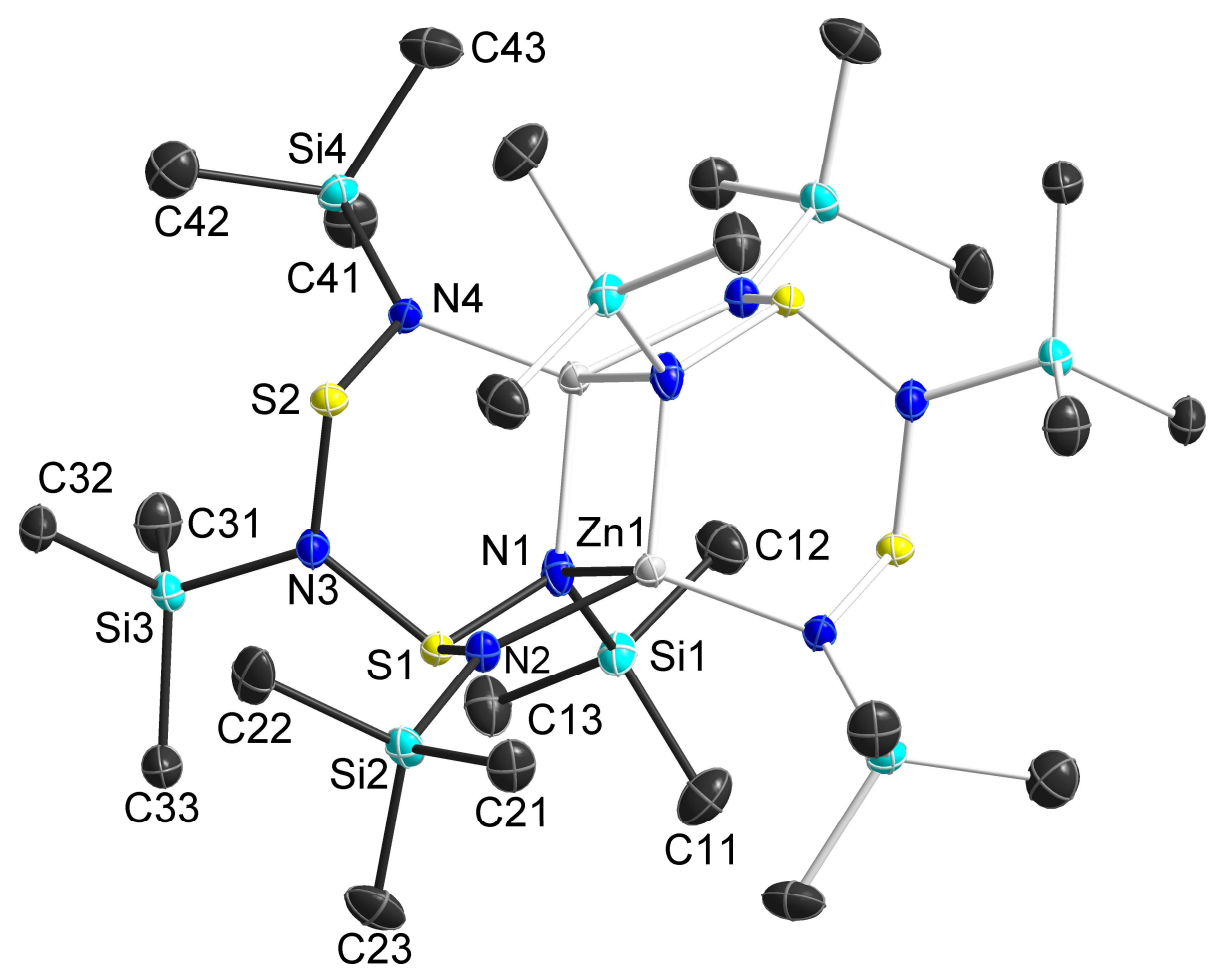


DuEPublico

Duisburg-Essen Publications online

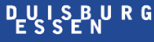

offen im Denken

This text is made available via DuEPublico, the institutional repository of the University of Duisburg-Essen. This version may eventually differ from another version distributed by a commercial publisher.

DOI: $\quad$ 10.1021/acs.organomet.5b00407

URN: urn:nbn:de:hbz:464-20201125-114201-8

This document is the Accepted Manuscript version of a Published Work that appeared in final form in: Organometallics 2015, 34, 13, 3421-3427, copyright (C) American Chemical Society after peer review and technical editing by the publisher. To access the final edited and published work see: https://doi.org/10.1021/acs.organomet.5b00407

All rights reserved. 